\title{
INFLUENCE OF THE TIMBER ELASTIC MODULUS ON THE GEOMETRIC NONLINEAR STRUCTURAL ANALYSIS OF TRUSS ARCHES
}

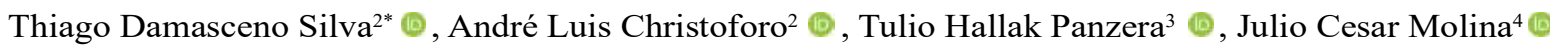 \\ and Francisco Antonio Rocco Lahr ${ }^{5}$ (P)
}

\footnotetext{
${ }^{1}$ Received on 16.08.2021 accepted for publication on 15.12.2021.

${ }^{2}$ Universidade Federal de São Carlos, Departamento de Engenharia Civil, São Carlos, SP- Brasil. E-mail: < damasceno.tds@gmail.com> and<christoforoal@yahoo.com.br>.

${ }^{3}$ Universidade Federal de São João del Rei, Departamento de Engenharia Mecânica, São Joaão del Rei, MG - Brasil. E-mail: <panzera@ ufsj.edu.br>.

${ }^{4}$ Universidade Estadual Paulista, Faculdade de Engenharia, Itapeva, SP - Brasil. E-mail: <julio.molina@unesp.br>.

${ }^{5}$ Universidade de São Paulo, Departamento de Engenharia de Estruturas, São Carlos, SP - Brasil. E-mail: <frocco@sc.usp.br>.

*Corresponding author.
}

\begin{abstract}
In this work, it was numerically evaluated the influence of the modulus of elasticity parallel to the wood grain on the stability of trussed arches considering a nonlinear geometric analysis based on the Finite Element Method (FEM). This approach was carried out according to a positional formulation of the FEM, considering the structural nodes as main variables of the nonlinear equations system, whose resolution was obtained using the Newton-Raphson method. Altogether, seven arch models were evaluated, consisting of coniferous and hardwoods, with properties defined according to the strength classes of the Brazilian standard ABNT NBR 7190. The subroutines were written in MATLAB to solve the system of nonlinear equations and perform the analysis, including the graphical representation of the results and configurations of the trussed arch. Internal loads and displacements were obtained, in addition to the instability loads of the trussed arches. It was found that the instability load of the arch made with the stiffest hardwood (D60) was approximately equal to $700 \%$ of the instability load of the $\mathrm{C} 20$ coniferous class and equivalent to $257.8 \%$ of the D20 hardwood class-related load. It was verified that the modulus of elasticity significantly influences the nonlinear geometric behavior of the timber trussed arch. Furthermore, the nonlinear geometric analysis allowed calculating more accurate parameters and the verification of the stability of the structural system.
\end{abstract}

Keywords: Timber structures; Finite Element Method; Positional formulation.

\section{INFLUÊNCIA DO MÓDULO DE ELASTICIDADE DA MADEIRA NA ANÁLISE ESTRUTURAL NÃO LINEAR GEOMÉTRICA DE ARCOS TRELIÇADOS}

\begin{abstract}
RESUMO - Neste trabalho avaliou-se numericamente a influência do módulo de elasticidade paralelo às fibras da madeira na estabilidade de arcos treliçados, considerando uma análise não linear geométrica baseada no Método dos Elementos Finitos (MEF). Essa abordagem foi realizada conforme uma formulação posicional do $M E F$, atribuindo-se os nós da estrutura como variáveis principais do sistema de equações não lineares, cuja resolução foi alcançada pelo método de Newton-Raphson. Ao todo, sete modelos de arco foram avaliados adotando-se madeiras coníferas e folhosas, com propriedades definidas segundo as classes de resistência da norma brasileira ABNT NBR 7190. Subrotinas foram desenvolvidas em linguagem MATLAB para resolução do sistema de equações não lineares e processamento da análise, incluindo a representação gráfica dos resultados e configurações do arco treliçado. Valores de esforços internos e deslocamentos foram determinados, assim como as forças de instabilidade dos arcos treliçados. Verificou-se que a força de instabilidade do arco constituído pela madeira folhosa mais rígida (D60) foi aproximadamente igual a 700\% da força de instabilidade referente à classe conifera C20, e equivalente a 257,8\% da força associada à classe folhosa D20. Concluiu-se que o módulo de elasticidade apresentou influência significativa no comportamento não linear geométrico do arco treliçado de madeira. Além disso, a análise não linear geométrica possibilitou o cálculo de parâmetros mais precisos e a verificação da estabilidade do sistema estrutural.
\end{abstract}

Palavras-Chave: Estruturas de madeira; Método dos Elementos Finitos; Formulação posicional.

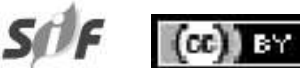

Revista Árvore 2022;46:e4608 http://dx.doi.org/10.1590/1806-908820220000008 


\section{INTRODUCTION}

Wood has numerous advantages when used as a structural material, such as the excellent relationship between mechanical strength and self-weight and relatively easy manufacturing. As a material extracted from a renewable source, with wide application possibilities in civil construction, wood directly contributes to developing more sustainable structures in terms of human action and the use of natural resources (Calil Junior et al., 2003).

In the last decades, several advances related to the strength capacity of wooden structures have been observed, including the industrialisation of composites and structural reinforcements. This fact, associated with the natural strength capacity of wood (Lahr et al., 2016), leads to an increase in the construction of slender elements. These elements are associated with lower consumption of materials and have several structural applications (Zangiácomo et al., 2014; Christoforo et al., 2016).

Despite the advantages of the slender and more flexible elements, it is evident that the structure can suffer large displacements and instability depending on its physical and geometrical properties. In this case, the equilibrium analysis based on the initial structure configuration is not entirely accurate, and must be avoided (Crisfield, 1990). Therefore, a formulation that allows the nonlinear geometric analysis of the structure must be prioritised to evaluate its behaviour according to the deformation. The positional formulation based on the Finite Element Method (FEM), conceived by Coda (2003), is an attractive option due to the computational capacity of its approach and the accuracy of the results. This formulation can be adapted to the nonlinear geometric analysis of timber trusses, as noted by Silva et al. (2020) and Silva et al. (2021).

One of the parameters used to assess the deformation of timber structures is the modulus of elasticity. As wood is an anisotropic material, and its properties may differ depending on the load direction, the estimation of the modulus of elasticity is generally carried out from two main directions: parallel to the fibres $\left(E_{0}\right)$ and normal to the wood fibre $\left(E_{90}\right)$. In trussed and timber structural systems, the bar elements are usually processed and positioned to support loads in a direction parallel to the wood fibres, considered more rigid and resistant due to the alignment of the cellulose fibres in this direction (Holmberg et al., 1999).

The modulus of elasticity and several other physical and mechanical properties differ according to wood species. Other factors also contribute to the variation in the modulus of elasticity of the same wood species, such as the climate and region of origin of the trees, the extraction of samples from different locations on the trunk, natural defects, wood dryness, among others (Hu et al., 2015). The value of the modulus of elasticity also varies according to the wood moisture content, decreasing as it increases (Silva et al., 2012). Due to the thousands of coniferous and hardwood species, wood structure design codes allow the standardisation of material properties according to strength classes. Standard values of strength and stiffness can be initially adopted according to a given strength class. Structural analysis and design can be done, and a species with similar mechanical properties can be chosen for a specific application (Firmanti et al., 2005).

This work sought to evaluate the numerical influence of the modulus of elasticity parallel to the wood grain on the stability of truss arches from a nonlinear geometric analysis, with positional formulation using the Finite Element Method. Therefore, seven structural models were proposed for analysis, considering the strength classes of conifers and hardwood based on NBR 7190 (ABNT, 1997). In the nonlinear geometric analysis, three main parameters were considered (i) the nodal displacements, (ii) the internal loads on the elements and (iii) the critical instability loads of the system.

\section{MATERIAL AND METHOD}

\subsection{Structural system properties}

The timber truss arch proposed for analysis is illustrated in Figure 1. This arch is bi-hinged and statically indeterminate. In general, this system is an efficient option for wooden roofs with medium or long spans, above $25 \mathrm{~m}$, as Lahr (1978) discussed. The timber truss arch can also be used in bridges, sheds, gymnasiums and other constructions, as it allows the space between the horizontal line of the span and the lower chord (Dickson and Parker, 2015).

Revista Árvore 2022;46:e4608 


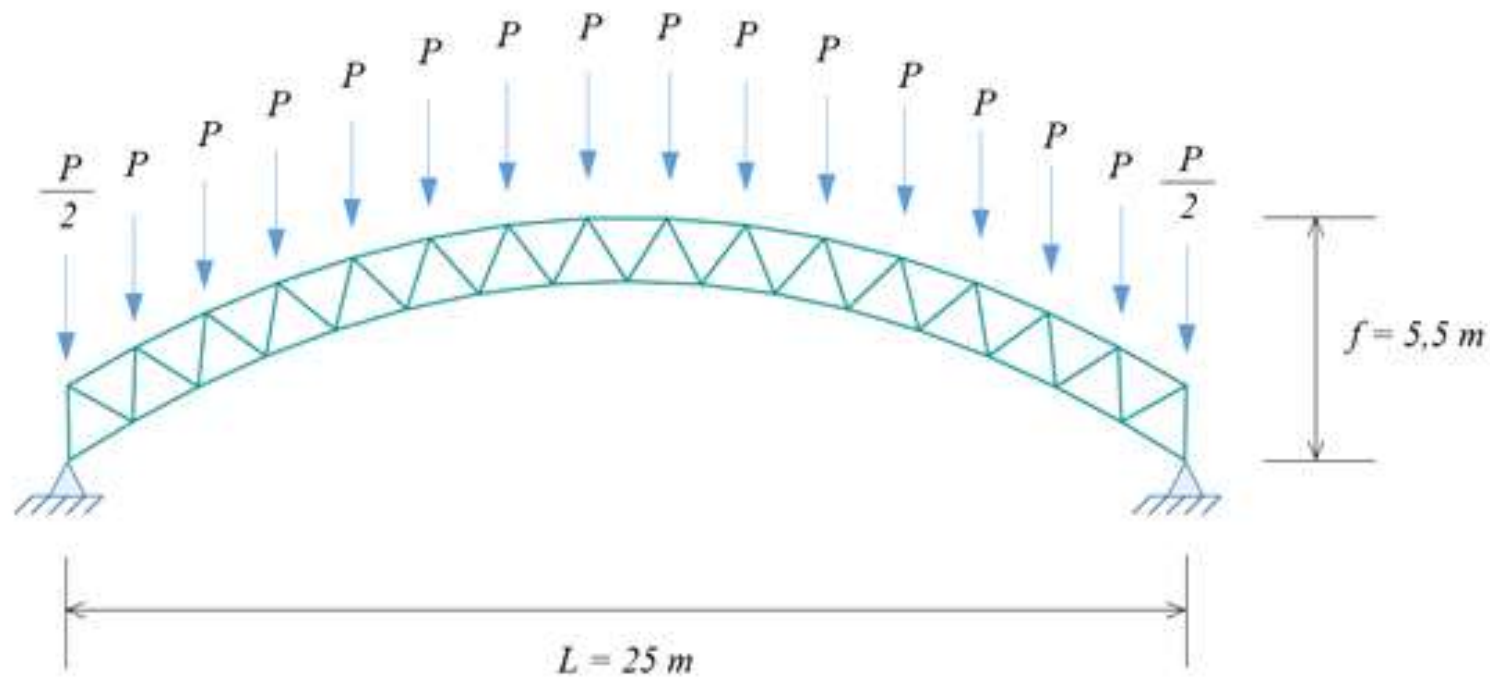

Figure 1 - Timber truss arch structural model.

Figura 1 - Modelo estrutural do arco treliçado.

Seven wooden truss arch models were defined, with a maximum height $(f)$ equal to $5.5 \mathrm{~m}$ and a span between supports $(L)$ of $25 \mathrm{~m}$. A distance of $1.5 \mathrm{~m}$ separates the chords at the midpoint. A twodimensional structural model was adopted, as shown in Figure 1. Due to the symmetry of the arch and the areas of influence, vertical loads $P$ were applied to the internal nodes of the upper chord and half of this load to the end nodes. The diagonal members were arranged so that the internal load occurs parallel to the wood fibres, with the joints being considered perfectly hinged.

Timbers from coniferous and hardwood groups were considered, with strength classes proposed by the Brazilian standard NBR 7190 (ABNT, 1997). The strength class of wood varied in each model, and the moduli of elasticity parallel to the fibres $\left(E_{0}\right)$ are shown in Table 1 . The normative values of $E_{0}$ are valid for the wood moisture rate $U=12 \%$.

The initial positions of the lower and upper chords of the truss arches were defined as a parabolic curvature, whose y-axis coordinates depend on the $\mathrm{x}$-axis coordinates, as per Equation 1 (Lahr, 1978). In this expression, the maximum height measured vertically is represented by $f$, and $L$ is the span between supports.

$y=\frac{4 \cdot f}{L^{2}} \cdot x \cdot(L-x)$

Eq. 1
To simulate parabolic curvature, the arch chords were split into straight inclined elements, avoiding the need for bending during construction. The diagonals were approximately equal in length to the members used in chords, similar to Warren's design of trusses (Timoshenko, 1953).

The chords elements had a cross-section consisting of two rectangular pieces measuring $6 \times 12$ $\mathrm{cm}^{2}$, spaced $6 \mathrm{~cm}$ apart, with a gross area of $144 \mathrm{~cm}^{2}$. A T-type cross-section in the diagonals was adopted, having a web of $6 \times 12 \mathrm{~cm}^{2}$ and a flange of $3 \times 12 \mathrm{~cm}^{2}$, with gross area equal to $108 \mathrm{~cm}^{2}$ in total. These dimensions were also used by Lahr (1978).

\subsection{Analysis procedure}

The nonlinear analysis was based on the positional formulation of the Finite Element Method presented

Table 1 - Modulus of elasticity $E_{0}$ of timber according to NBR 7190.

Tabela 1 - Módulo de elasticidade $E_{0}$ de madeiras classificadas conforme NBR 7190.

\begin{tabular}{lrr}
\hline Arch model & Strength class of wood & \multicolumn{2}{c}{$\begin{array}{c}\text { Modulus of } \\
\text { elasticity } E_{0}(\mathrm{GPa})\end{array}$} \\
\hline 1 & C20 & 3.50 \\
2 & C25 & 8.50 \\
3 & C30 & 14.50 \\
4 & D20 & 9.50 \\
5 & D30 & 14.50 \\
6 & D40 & 19.50 \\
7 & D60 & 24.50 \\
\hline
\end{tabular}


by Greco et al. (2006). In summary, the positional formulation relates to the principle of minimum total potential energy, with the Cartesian coordinates of the truss nodes adopted as the main variables of the system (Coda, 2018). The total potential energy (I) of an element is defined by the difference between the strain energy $(U)$ and the potential energy of the external loads $(W)$, expressed in Equation 2.

$$
\Pi=U-W
$$

The total strain energy is a function of the element volume $(V)$, according to Equation 3. In this expression, the normal stress is represented by $\sigma$, and $\varepsilon$ is the strain of the element.

$U=\int_{V} \int_{\underline{\underline{\varepsilon}}} \underline{\sigma} d \underline{\varepsilon} d V=\int_{V} \frac{1}{2} \cdot E \underline{\varepsilon}^{2} d V$

The potential energy of applied loads is indicated in Equation 4, where $F$ represents the set of applied loads and $Y$ the set of independent positions that can be occupied by a point on the element.

$W=\sum F \cdot Y$

A simple strain measure (Equation 5) is adopted for analysis. The initial length of the element is defined by $L_{0}$, while $L$ is the length after deformation.

$\underline{\varepsilon}=\frac{L}{L_{0}}-1$

A nonlinear equations system is reached considering a stationary condition. This is represented by the null partial derivatives of the total potential energy function with respect to the nodal coordinates variables (Equation 6).

$$
\frac{\partial \Pi}{\partial Y}=0 \Leftrightarrow F_{\text {int }}=F_{\text {ext }}
$$

The Newton-Raphson Method is adopted to solve nonlinear equations, whose procedure is incrementaliterative and seeks to find a new set of positions that satisfies Equation 6. The total loading is divided into incremental steps, which are gradually applied to the structure. Then, the partial derivative vector $(g)$ and the Hessian matrix $(\nabla g)$ of the total potential energy are determined for the set of positions. The initial nodal coordinates, grouped in the set $Y_{0}$, are adopted in the first iteration. Sequentially, the position correction vector, called $\Delta Y$, is calculated from Equation 7, which represents the stationary condition of the system.
$g(Y)+\nabla g(Y) \cdot \Delta Y=0$

Once the vector $\Delta Y$ is obtained, the nodal coordinates of the structure are updated according to Equation 8, where $Y$ is the set of updated nodal coordinates. Further iterations are developed in sequence until the vector norm $\Delta Y$ is sufficiently small, typically less than $10^{-6}$. This procedure is repeated for each loading step, adopting the last $Y$ value found.

$Y=Y_{0}+\Delta Y$

The arch carries loads by compression and can be affected by in-plane or out-of-plane buckling instability (Rodman et al., 2013). In this case, the arches had sufficient rigidity and restrictions to prevent out-of-plane instability, whose approach is not studied in this work.

In-plane instability can be assessed when a critical condition is reached during loading, being characterised by a qualitative change in the equilibrium state (Greco and Venturini, 2006). The arch equilibrium is stable when the Hessian matrix is positive defined, whose determinant is also positive. When the determinant is null (Equation 9), the Hessian matrix becomes singular and a critical condition is reached, usually a bifurcation point of the equilibrium trajectory (Shi, 1996). The load that implies the singularity of the Hessian matrix is the instability load $\left(P_{c r}\right)$, associated with the arch instability.

$\operatorname{det}(\nabla g(Y))=0$

A computational implementation was developed using MATLAB, with subroutines written according to the steps and equations involved in nonlinear geometric analysis. A tolerance of $10^{-7}$ was considered for the $\Delta Y$ vector norm, determined according to the system solution by the Newton-Raphson method. This tolerance was adopted at each load stage.

It is important to mention that the strength or ultimate loads of timber trussed arches were not evaluated in this work.

\section{RESULTS}

From the nonlinear geometric analysis performed, two graphs were obtained, as presented in Figure 2. In general, these graphs showed the variation of linear and nonlinear geometric analysis results, and the latter clearly provides more unfavorable values. The first 
graph (Figure 2A) was related to the displacement of the upper chord central node and the external load applied. The results were related to the seven wood classes proposed by the Brazilian standard NBR 7190
(ABNT, 1997), used in each model. The linear results were represented by straight lines with different inclinations. The displacements for classes C30 and D30 were similar, as the modulus of elasticity parallel

A

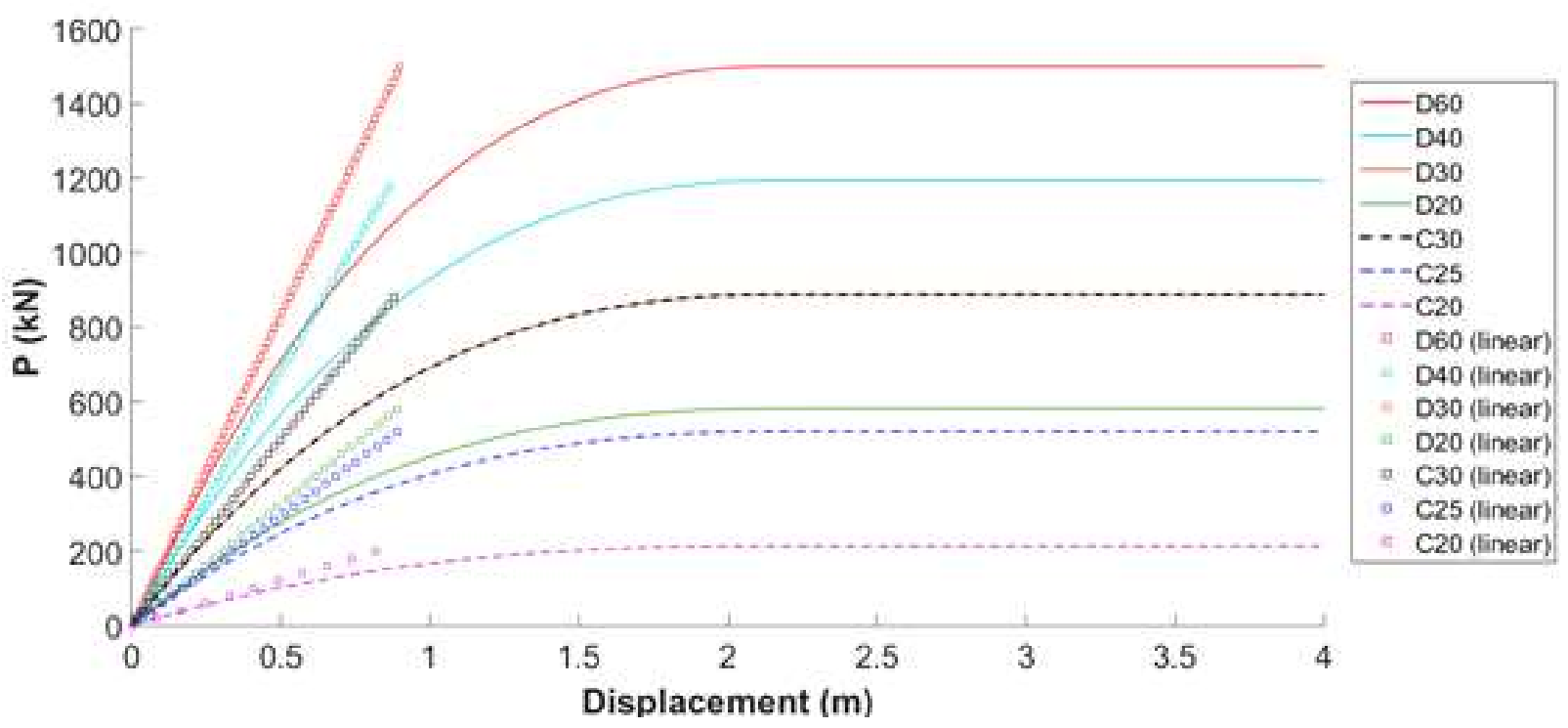

B

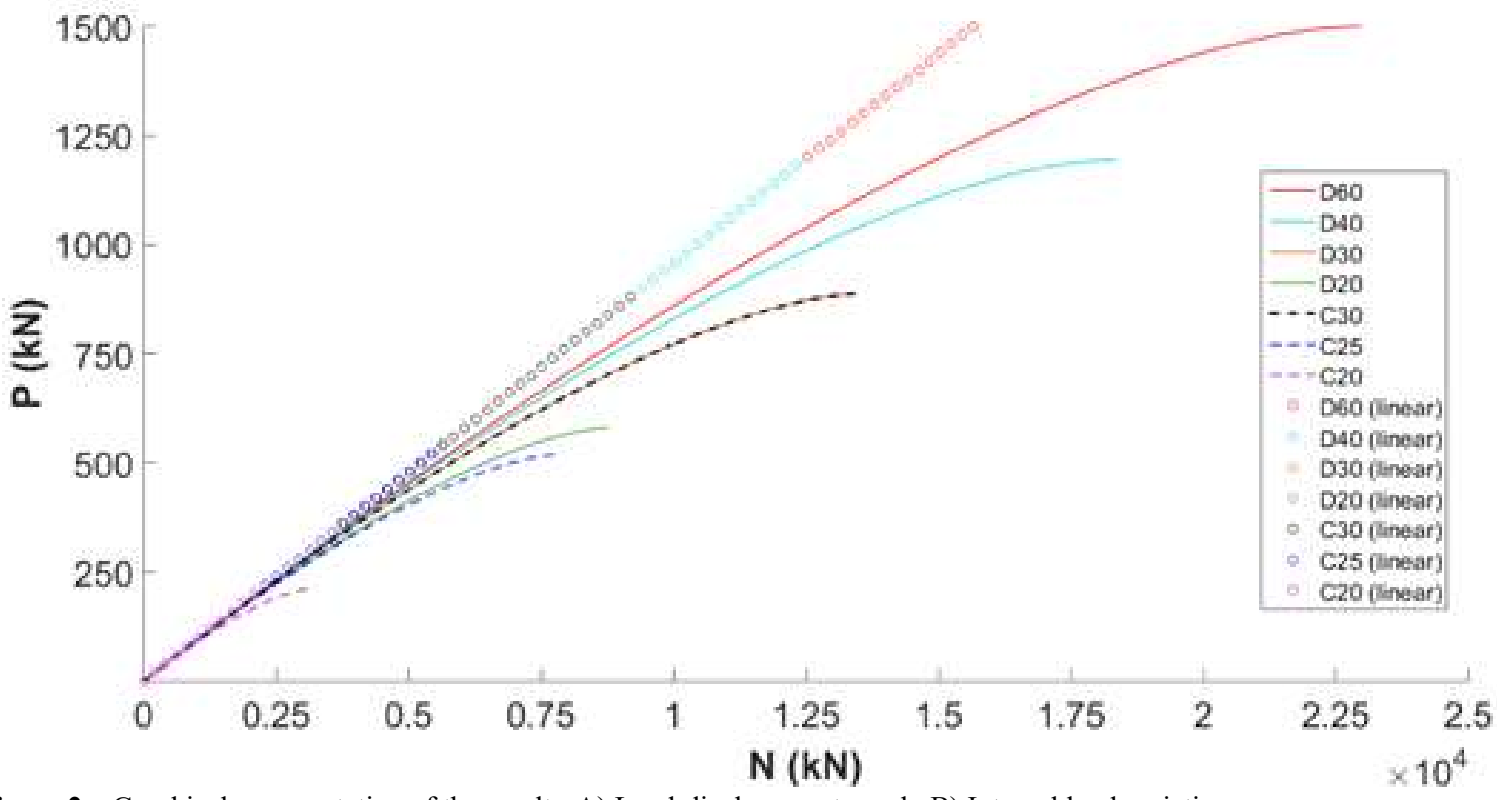

Figure 2 - Graphical representation of the results. A) Load-displacement graph. B) Internal load variation.

Figura 2 - Representação gráfica dos resultados. A) Gráfico força-deslocamento. B) Variação da força interna. 
to the wood fibres remained identical under these circumstances.

Figure $2 \mathrm{~B}$ showed the variation of the internal load $(N)$ on the most critical element with the intensity of the external loads applied. In all cases, the internal load was compressive and values were absolute. The results were obtained considering the application of external loads until the imminence of instability in each model. One straight line displays the linear results, as there was no variation in the inclination according to the wood. Again, the results for classes C30 and D30 were equivalent due to the modulus of elasticity similarity.

The nonlinear results in Figure 2A indicate that the displacements increase significantly after instability, also varying according to the model. The instability load was equivalent to the value of $P$ referring to the load step in which the determinant of the Hessian matrix becomes null, as mentioned in Equation 9. The loads associated with the critical instability point were represented in Table 2, depending on the wood classification. Each instability load $\left(P_{c r}\right)$ was divided by the loads of model C20 $\left(P_{c r, C 20}\right)$ and model D20 $\left(P_{c r D 20}\right)$, which were the lower stiffness classes of conifers and hardwoods considered in this work, respectively, and by the loads of instability of the model D60 (stiffest hardwood). It must be noted that the instability loads cannot be directly estimated by the geometric linear analysis.

The deformed truss arch configuration associated with model 1 (coniferous wood C20) is illustrated in Figure 3, where the application of external loads was less than the respective instability load in the first situation (Figure 3A) and greater than the instability load in the second case (Figure 3B). These representations were obtained with MATLAB from the developed subroutine in the post-processing step of the analysis.
To verify the internal load distribution on the elements during the post-processing stage, a graphical representation (Figure 3C) was also implemented from the code. A colour scheme was programmed to simulate the variation of the internal load of each truss element, based on a red, green and blue pattern (RGB). Elements that perform maximum compression were illustrated in dark blue, while elements in dark red were subject to maximum tension. Elements highlighted in green received internal loads with lower values, including those close to null. The elements most affected by compression were located on the lower chord and close to the supports, and the elements most tensioned are the internal diagonals.

When instability occurs, there is a reversal of the internal loads on the elements, and the values highlighted in Figure 3C may diverge, as well as the possible representation of colours. In the specific case of the most compressed element, it becomes tensioned after instability and vice versa.

\section{DISCUSSION}

Data associated with nonlinear analysis of timber trusses are rare in the literature, and most of these publications focus on the nonlinearity of the material. Consequently, a general positional formulation of the FEM was adopted for the nonlinear geometric analysis, based on the works of Coda e Greco (2004), Greco et al. (2006) and Greco and Venturini (2006). The present analysis was adapted for timber truss arches, considering the seven-strength wood proposed by NBR 7190 (ABNT, 1997). The constraints of this study were related to the simplified hypothesis assumed in the analysis, including the joints idealised as perfect hinges to model the truss arch and the constant values of the modulus of elasticity parallel to the wood grain.

Table 2 - Instability load comparison values.

Tabela 2 - Comparação das forças de instabilidade.

\begin{tabular}{lcccc}
\hline Arch model & Strength class of wood & $P_{c r}(\mathrm{kN})$ & $P_{c r} / P_{c r, C 20}$ & $P_{c r} / P_{c r, D 20}$ \\
\hline 1 & C20 & 214.5 & 1.000 & 0.369 \\
2 & C25 & 520.5 & 2.427 & 0.143 \\
3 & C30 & 888.0 & 4.140 & 0.894 \\
4 & D20 & 582.0 & 2.713 & 1.526 \\
5 & D30 & 888.0 & 4.140 & 1.000 \\
6 & D40 & 1194.5 & 5.569 & 1.526 \\
7 & D60 & 1500.5 & 0.592 \\
\hline
\end{tabular}

Revista Árvore 2022;46:e4608 
A
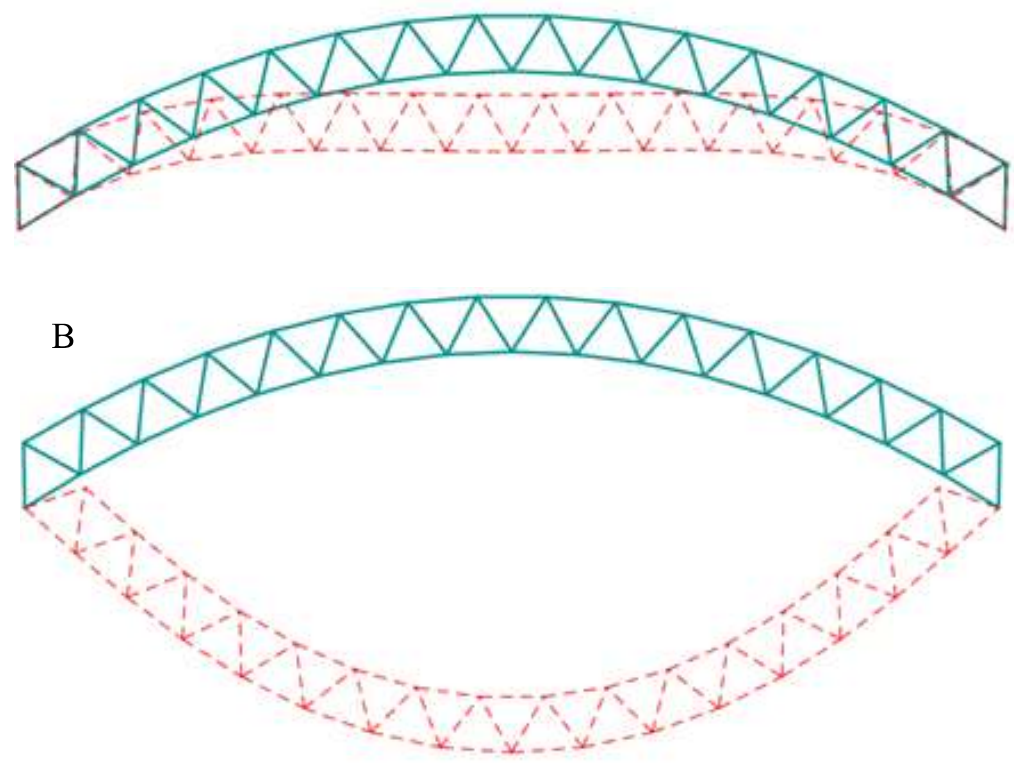

C Maximum tension

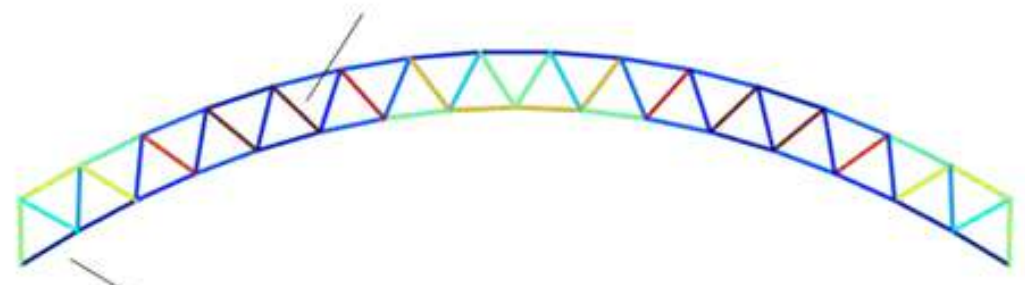

Maximum compression
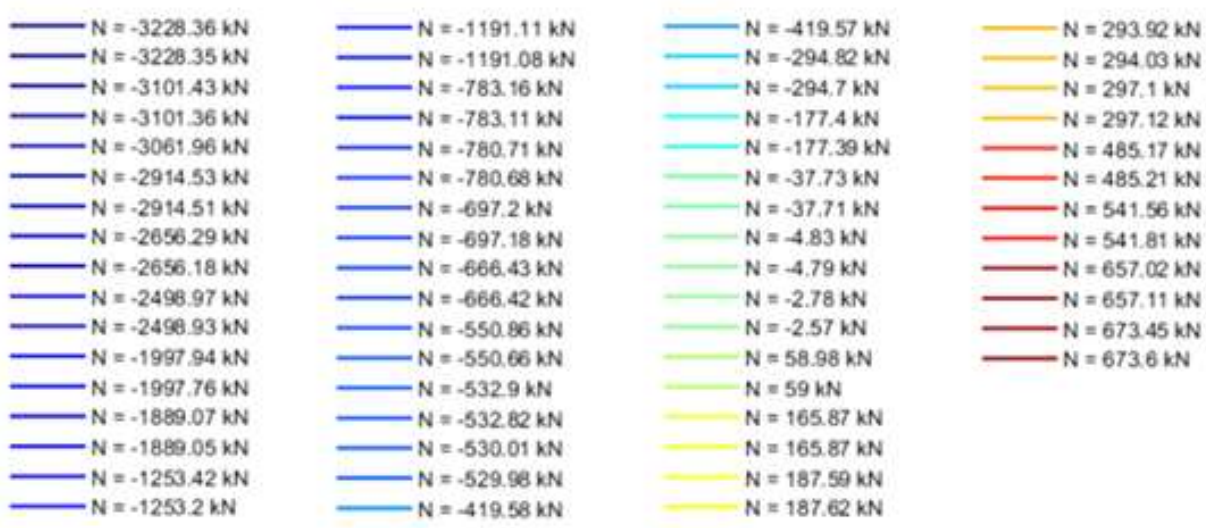

$>P \quad$ C) Graphical representation of internal loads in elements.

Figura 3 - Configurações do arco treliçado de madeira relacionadas ao modelo 1 . A) Configuração deformada quando $P<P$. B) Configuração deformada quando $P>P_{c r}$. C) Representação gráfica das forças internas nos elementos. 
As noted, the displacements, internal loads and instability loads were substantially influenced by the wood strength class and its modulus of elasticity. In all cases, the stiffer hardwood D60 had a superior response, exhibiting a higher instability load and lower displacements and internal loads. The results of models $\mathrm{C} 25$ and D20 reveal a variation of approximately $10 \%$, while the parameters of models C30 and D30 were equivalent due to the modulus of elasticity similarity.

As a reference for the class D60 hardwood model, the instability load was equivalent to approximately seven times $(700 \%)$ the value associated with the C20 coniferous wood model. The instability load related to the hardwood model D20 was equivalent to $38.8 \%$ of load of the hardwood model D60.

A graphical representation of the results was possible with MATLAB's subroutines, providing images generated automatically in the postprocessing stage. The positional formulation favoured the implementation of these subroutines, mainly by considering the nodal positions as main variables instead of displacements. For a post-processing stage, the use of a set of positions is straightforward compared to a set of displacements (Coda, 2018).

It should be noted that a simple linear geometric analysis would not tolerate the estimate of the instability loads of the truss structure, as observed by Greco and Venturini (2006). Also, the values of internal loads and displacements determined from a linear analysis was evidently smaller, as the obtained for the trussed arch, since a linear relationship between load and displacement was assumed. Therefore, a nonlinear geometric analysis similar to the one presented here should be prioritised in the design of timber structures, used in roofing and other constructive applications, to allow possible threats of instabilities to be predicted and avoided, in addition to supporting more accurate values for internal loads and displacements. Futhermore, a special attention should be paid to nonlinear geometric analysis procedures in future revisions of the Brazilian standard NBR 7190 (ABNT, 1997), to encourage its use and broaden the discussion on the subject. Currently, this standard does not consider any remarks on nonlinear analysis in its content.

\section{CONCLUSIONS}

The influence of the modulus of elasticity parallel to the wood grain on the stability of truss arches was evaluated from a nonlinear geometric analysis, using a positional formulation based on the Finite Element Method. Regarding the geometric nonlinear behaviour, the wood with a higher value of modulus of elasticity increased the strength capacity of the truss arches, since it directly affected the displacement and elements internal loads values. This advantage was also evidenced in the arches instability, since the instability load of the stiffest hardwood (D60) model was approximately equal to $700 \%$ of the instability load of the C20 model, and equivalent to $257.8 \%$ of the associated load to the D20 model.

Nonlinear geometric analysis was also pertinent, as it allowed for more accurate internal loading and displacements and the analysis of the stability of the structural system. The FEM positional formulation, due to the consideration of nodal positions as main variables, favoured the implementation of MATLAB subroutines and the graphical representation data in the post-processing stage. For these reasons, a discussion of geometric nonlinear analysis can be suggested for future revisions of the Brazilian standard ABNT NBR 7190, encouraging its application more frequently in design procedures.

\section{AUTHOR CONTRIBUTIONS}

Thiago Damasceno Silva contribuiu na redação do texto, programação, análise dos dados e interpretação dos resultados.

André Luis Christoforo contribuiu na análise dos dados, interpretação dos resultados e também na redação.

Túlio Hallak Panzera contribuiu com a tradução e redação do texto, além da pesquisa bibliográfica.

Julio Cesar Molina contribuiu na redação do texto e na pesquisa bibliográfica.

Francisco Antonio Rocco Lahr contribuiu com a redação do texto e preparação dos dados.

\section{ACKNOWLEDGMENTS}

The authors express their gratitude to the Conselho Nacional de Desenvolvimento Científico e

Revista Árvore 2022;46:e4608 
Tecnológico (CNPq: research grant 309058/2019-8), for providing funds and research scholarships.

\section{REFERÊNCIAS}

Associação Brasileira de Normas Técnicas - ABNT. NBR 7190: Projeto de estruturas de madeira. Rio de Janeiro: 1997.

Calil Junior C, Lahr FAR, Dias AA.

Dimensionamento de elementos estruturais de madeira. Barueri: Manole, 2003.

Christoforo AL, Panzera TH, Silveira ME, Silva DAL, Pinheiro RV, Lahr FAR. Avaliação numérica do módulo de elasticidade em vigas roliças de madeira da espécie Pinus elliottii. Ciência Florestal. 2016;26(4):1271-1279. doi:10.5902/1980509825138

Coda, HB. Análise não linear geométrica de sólidos e estruturas: uma formulação posicional baseada no MEF [full professor's thesis]. São Carlos: Escola de Engenharia de São Carlos, Universidade de São Paulo; 2003.

Coda HB, Greco M. A simple FEM formulation for large defletion 2D frame analysis based on position description. Computer methods in applied mechanics and engineering. 2004;193(1):3541-3557. doi:10.1016/j.cma.2004.01.005

Coda HB. O método dos elementos finitos posicional: análise estática e dinâmica. São Carlos: EESC/USP, 2018.

Crisfield MA. A consistent co-rotational formulation for nonlinear three dimensional beam-elements. Computer methods in applied mechanics and engineering. 1990;81(2):131-150. doi:10.1016/00457825(90)90106-V

Dickson M, Parker D. Engineered timber and structural form in sustainable design. Construction Materials. 2015;168(4):161-172. doi:10.1680/ coma.14.00058

Firmanti A, Bachtiar E, Surjokusumo S, Komatsu $\mathrm{K}$, Kawai S. Mechanical stress grading of tropical timbers without regard to species. Journal of Wood Science. 2005;51(1):339-347. doi:10.1007/s10086004-0661-z

Greco M, Gesualdo FAR, Venturini WS, Coda
HB. Nonlinear positional formulation for space truss analysis. Finite elements in analysis and design. 2006;42(12):1079-1086. doi:10.1016/j. finel.2006.04.007

Greco M, Venturini WS. Stability analysis of threedimensional trusses. Latin American Journal of Solids and Structures. 2006;3(3):325-344.

Holmberg S, Persson K, Petersson H. Nonlinear mechanical behaviour and analysis of wood and fibre materials. Computer and Structures. 1999;72(1):459480 .

Hu M, Johansson M, Olsson A, Oscarsson J, Bertil E. Local variation of modulus of elasticity in timber determined on the basis of non-contact deformation measurement and scanned fibre orientation.

European Journal of Wood and Wood Products. 2015;73(1):17-27. doi:10.1007/s00107-014-0851-3

Lahr, FAR. Arco treliçado de madeira [dissertação]. São Carlos: Escola de Engenharia de São Carlos, Universidade de São Paulo; 1978.

Lahr FAR, Christoforo AL, Silva CEG, Junior JRA, Pinheiro RV. Avaliação de propriedades físicas e mecânicas de madeiras de jatobá (Hymenaea stilbocarpa Hayne) com diferentes teores de umidade e extraídas de regiões distintas. Revista Árvore. 2016;40(1):147-154. doi:10.1590/010067622016000100016

Rodman U, Saje M, Planinc I, Zupan D. The lateral buckling of timber arches. International Journal of Structural Stability and Dynamics. 2013;13(8):1350040-16. doi:10.1142/ S0219455413500405

Shi J. Computing critical points and secondary paths in nonlinear structural stability analysis by the finite element method. Computers \& Structures. 1996;58(1):203-202. doi:10.1016/00457949(95)00114-V

Silva DAL, Lahr FAR, Faria OB, Chaud E. Influence of wood moisture content on the modulus of elasticity in compression parallel to the grain. Materials Research. 2012;15(2):300-304. doi:10.1590/S1516-14392012005000025

Silva TD, Christoforo AL, Lahr FAR. Aplicação 
do Método dos Elementos Finitos Posicional para análise não linear geométrica de treliças Howe de madeira. In: Anais do $4^{\circ}$ Congresso do Instituto Politécnico da PUC Minas; 20-22 out 2020; Belo Horizonte (MG): PUC Minas; 2020.

Silva TD, Christoforo AL, Narques TVN, Teixeira JN, Lahr FAR. Análise não linear geométrica de treliças planas de madeira a partir do método dos elementos finitos posicional. Principia. 2021;57:1-9. doi:10.18265/1517-0306a2021id5835

Timoshenko S. History of Strength of Materials. New York: McGraw-Hill; 1953.

Zangiácomo AL, Christoforo AL, Lahr FAR. Módulo de elasticidade aparente em vigas roliças estruturais de madeira Pinus elliottii. Ambiente Construído. 2014;14(1):7-13. doi:10.1590/S167886212014000100002 